Revision II

An Analysis of

Federal Incentives Used to Stimulate Energy Production

February 1980 Executive Summary

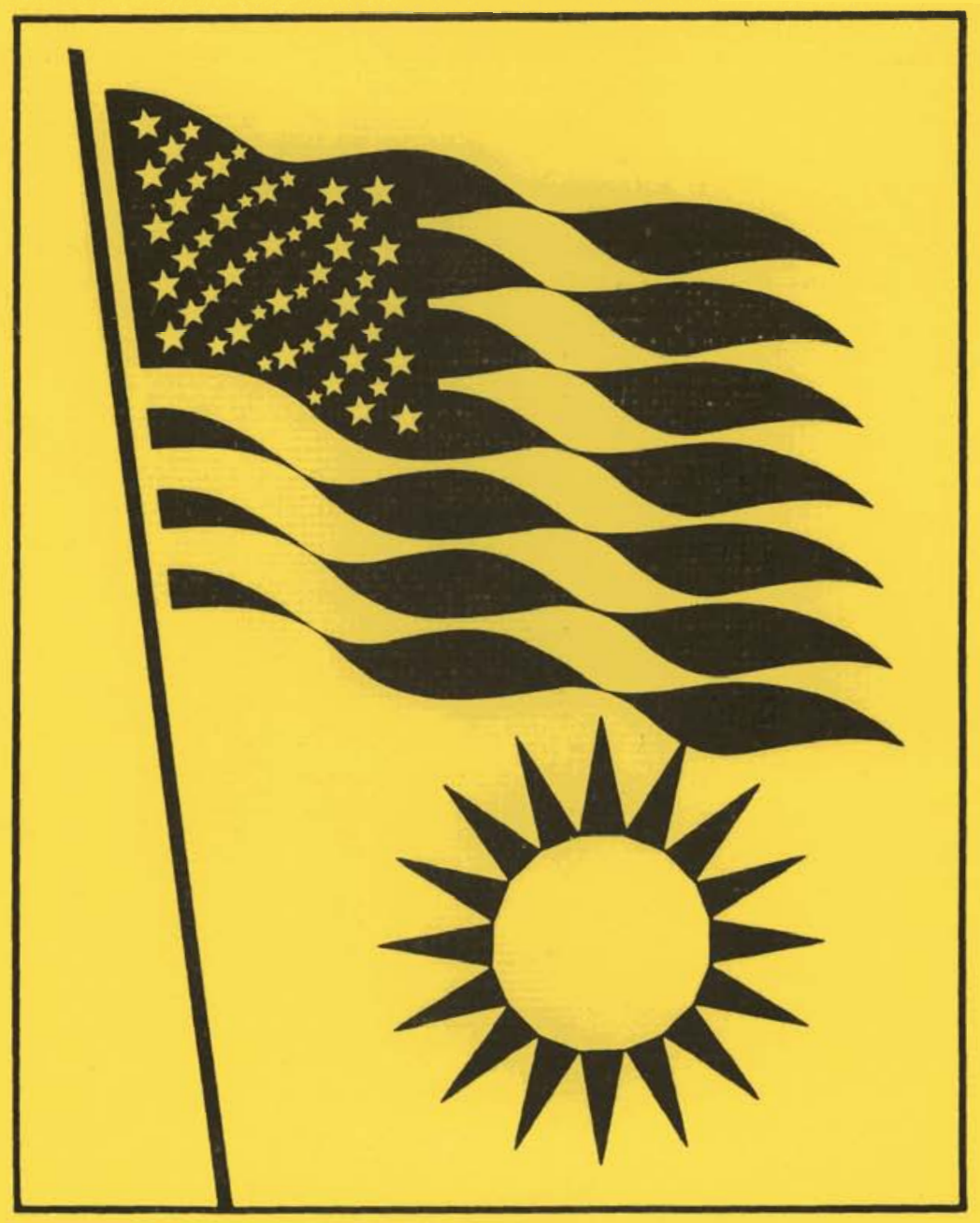

Prepared for the U.S. Department of Energy under Contract EY-76-C-06-1830

Pacific Northwest Laboratory Operated for the U.S. Department of Energy by Battelle Memorial Institute 


\title{
NOTICE
}

This report was prepared as an account of work sponsored by the United States Government. Neither the United States nor the Department of Energy, nor any of their employees, nor any of their contractors, subcontractors, or their employees, makes any warranty, expras or implied, or assumes any legal liability or responsibility for the accuracy, completeness or usefulness of any information. apparatus, product or process disclosed, or represents that its use would not infringe privately owned rights.

The views, opinions and conclusions contained in this repon are those of the contractor and do not necessarily represent those of the United States Government or t k United States Department of Energy.

\author{
PACIFIC NORTHWEST LABORATORY \\ operated by \\ BATTELLE \\ for the \\ UNITED STATES DEPARTMENT OF ENERGY \\ Under Contract EY-76-C-06-1830
}

Printed in the United States of A
Available from
National Technical Information S
United Siates Department of Com
5225 Port Royal Road
Springfield, Virginis 22151
Price: Printed Copy $\$$


REVISION II

AN ANALYSIS OF FEDERAL INCENTIVES

USED TO STIMULATE ENERGY PRODUCTION

An Executive Summary

B. W. Cone, D. L. Brenchley, V. L. Brix,

M. L. Brown, K. E. Cochran, P. D. Cohn, R. J. Cole,

M. G. Curry, R. Davidson, J. Easterling, J. C. Emery,

A G. Fassbender, J. S. Fattorini, Jr., B. Gordon,

H Harty, D. Lenerz, A R. Maurizi, R. Mazzucchi,

C. McClain, D. D. Moore, J. H. Maxwell, W. J. Sheppard

S. Solomon, P. Sommers

February 1980

Prepared for

Division of Conservation

of Solar Applications

Department of Energy

Washington, DC 20545

under Contract EY-76-C-06 1830

Pacific Northwest Laboratory

Richland, Washington 99352 

CONTENTS

AN ANALYSIS OF FEDERAL INCENTIVES USED TO STIMULATE

ENERGY PRODUCTION $\cdot$. GENERIC INCENTIVES • • • • • • • • • • •

NUCLEAR INCENTIVES $\cdot$ • $•$ •

HYDRO INCENTIVES.$+\cdot$ •

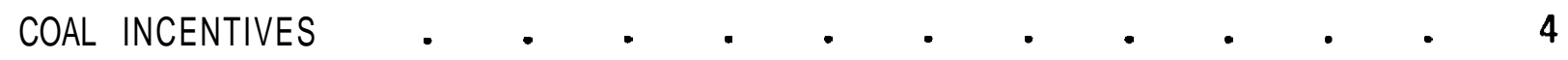

OIL INCENTIVES . $\cdot$ •

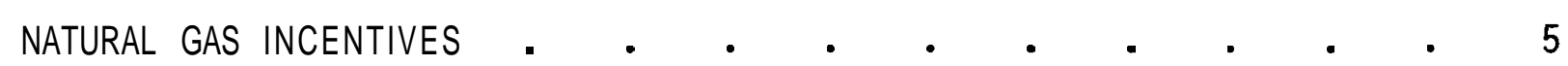

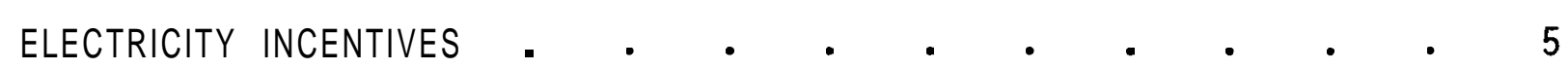

CONCLUSIONS • 



\title{
AN ANALYSIS OF FEDERAL INCENIIVES \\ USED TO STIMULATE ENERGY PRODUCTION
}

\author{
An Executive Summary
}

The amount of solar energy that reaches the earth's surface every two weeks is equivalent to all of the known reserves of coal, gas, and oil. Yet, the use of this energy source to generate electricity and heat and cool buildings is negligible.

Debate over solar energy's role has caused policy makers to speculate on the reasons for the large difference between present and potential uses of solar energy. These reasons appear to be buried in complex technical, economic, legal, institutional, and political interrelationships. An improved understanding of forces that have shaped the existing energy budget may provide insights for the future.

The purpose of this research was to analyze past and present Federal incentives to production of various energy sources and thereby assist the Division of Conservation and Solar Applications, Department of Energy, in the study and recommendation of Federal incentives for the development of solar energy. The research was divided into five parts: a survey of current thought about incentives for solar energy production; the theoretical approach to analyzing and characterizing incentives; a generic view of the energy incentive creating landscape for 1978; analysis of the major energy sources (nuclear, hydro, coal, electricity, oil, and gas) along their trajectories from exploration to waste management, including their costs in 1978 dollars; and insights into potential incentives for solar policy.

Economic, political, organizational, and legal viewpoints were considered in formulating the typology of incentives. The following eight types of Incentives were identified:

1) Creation or prohibition of organizations that carry out actions,

2) Taxation exemption, or reduction of existing taxes, 
3) Collection of fees for delivery of a governmental service or good,

4) Disbursements in which the Federal Government distributes money without requiring anything in return,

5) Requirements made by the government backed by criminal or civil sanctions,

6) Traditional government services provided through a nongovernmental entity without direct charge (i.e., regulating interstate and foreign commerce and providing inland waterways),

7) Nontraditional government services such as exploration, research, development and demonstration of new technology,

8) Market activity under conditions similar to those faced by nongovernmental producers or consumers.

\section{GENERIC INCENTIVES}

Using this typology of Federal actions, incentives provided during FY-1978 were identified on a generic basis. Forty-five organizational components spent an estimated $\$ 13.7$ billion conducting energy-related activities. Expenditures of individual organizations ranged from $\$ 4.89$ bi 11 ion, spent by the Department of Energy (DOE) to negligible amounts. The DOE, the Tennessee Valley Authority, and the Army Corps of Engineers accounted for $76 \%$ of the incentives expended. Twenty-eight departmental agencies administered $\$ 9.25$ billion in energy programs. Eleven Senate committees had jurisdiction over energy-related organizations, the largest of which, the Energy and Natural Resources Committee, had jurisdiction over 14 organizations with a total outlay of $\$ 10.24$ billion. Fourteen House committees had jurisdiction over energy-related organizations; these included the Government Operations Committee, which had jurisdiction over 21 organizations with a total outlay of $\$ 12.63$ billion.

Organizations emphasizing market activity spent $52 \%$ of all funds. Exploration, research, development, and demonstration accounted for $38.5 \%$. Organizations whose primary action involved requirements backed by criminal and civi 1 sanctions spent 5.5\%. Only one organization was involved in altering the tax structure. 
Twenty-nine percent of the $\$ 13.7$ billion was directly related to incentives involving electricity, mostly for market activities. Of the remaining $71 \%$, $\$ 5.59$ billion was expended for incentives to the nuclear industry. The o il industry received $\$ 1.65$ billion. Coal received $\$ 1.63$ billion and gas received less than $\$ 300$ million. The solar energy industry received $\$ 371 \mathrm{mil}$ lion of the incentives directed specifically toward energy-producing industries.

\section{NUCLEAR INCENTIVES}

Incentives for nuclear power are estimated to have cost the Federal Government $\$ 21.0$ billion over the past 30 years. This was about $8.3 \%$ of total Federal incentives to stimulate energy production. The Civilian Reactor Development Program (CRDP) used approximately $81 \%$ of the research and development dollars allocated to commercial nuclear power by DOE The Liquid Metal Fast Breeder Reactor (LMFBR) program has received $\$ 4.4$ billion through the CRDP. The costs of regulating civilian reactors ( $\$ 1.65$ billion) and the investment in enrichment plants ( $\$ 2.1$ billion) were included in the total costs.

The total costs of incentives to the nuclear industry do not take into account several nonquantifiable incentives, namely the cost of the PriceAnderson Act (a legislative action which removed the liability insurance roadblock) and Federal uranium policies. No way was found to quantify them.

\section{HMDRO INCENTIVES}

The estimated cost of incentives to hydroelectric power was $\$ 16.9$ billion. This is $6.7 \%$ of the total Federal incentives to stimulate energy production. In the development of hydropower, the government has acted primarily as a market entity in each step of the production-consumption cycle. Most of the incentives used to stimulate hydro energy production would, therefore, be categorized as market activity. Two procedures were used to quantify the incentives. For the first, return on investment from power revenues and costs of construction, operation, maintenance, management, and regulation of dams 
(that could be allocated to power development) were calculated. For the second, subsidies provided by the low interest rates on Federal loans were calculated. The total incentive costs based on either procedure include regulation cost and the incentives from tax exempt power revenues. Using the first procedure, it was estimated that the costs of incentives were $\$ 16.9$ billion for hydroelectric generation. With the second, the costs were $\$ 8.9$ billion.

\section{COAL INCENIIVES}

The depletion allowance has been the single largest incentive to increased coal production. It amounted to $\$ 4.7$ billion between 1950 to 1978. Traditional services, which include facilities to aid the water-borne movement of coal, amounted to $\$ 2.6$ billion between 1950 and 1978. The nontraditional services of research, exploration, development, and safety accounted for \$3.6 billion of incentives. An estimated $\$ 11.7$ billion has been expended for incentives to the coal industry, or $4.6 \%$ of the total cost of incentives.

\section{OIL NCENIIVES}

Incentives to oil production were considered as two categories: 1) exploration and production and 2) refining and distribution. Exploration and production was defined to include the search for and recovery of both crude oil and natural gas, so that incentives to the exploration and production of one of these energy sources acted as an incentive to the other. However, refining and distribution was limited to petroleum conversion.

An estimated $\$ 123.6$ billion has been expended for incentives to the oil industry. This was $49 \%$ of the total Federal incentives to stimulate energy production. A large incentive to the petroleum industry was the reduction of existing taxes through intangible drilling expensing and the percentage depletion allowance. This incentive amounted to $\$ 55.5$ billion. Requirements, including stripper well price incentives, incentives for new oil, subsidies for pipelines and the Federal Energy Administration (now the ERA), had an estimated value from 1921 to 1978 of $\$ 57.5$ billion. Traditional services, 
such as the maintenance of ports and waterways to handle o il tankers, accounted for $\$ 6.9$ billion. Research and development and data collection by the Geological Survey and Bureau of Mines accounted for $\$ 1.9$ billion of incentives. Disbursements ( $\$ 1.3$ billion) and market activity ( $\$ 0.5$ billion) accounted for a small percentage of the total cost of incentives to oil.

\section{NATURAL GAS INCENTIVES}

An estimated $\$ 14.6$ billion was expended for incentives to the natural gas industry between 1950 and 1978 . This was $5.8 \%$ of total incentives to energy production. Most of the incentives were in the form of exemptions or reductions of existing taxes. Intangible drilling expensing and the percentage depletion allowance accounted for $\$ 14.9$ billion. Requirements in the form of wellhead price controls were disincentives to the natural gas industry of $\$ 0.8$ billion. Nontraditional services (which included data from the Bureau of Mines and the Geological Survey) and market activity accounted for $\$ 0.45$ billion.

\section{ELECTRICITY INCENTIVES}

The total cost of incentives for electricity generation and transmission were $\$ 64.5$ billion or $25.6 \%$ of the total energy incentives provided by the Federal Government to the six major energy sources.

To estimate the value of incentives, the analysis distinguished between the investor-owned private utilities and the government sponsored utilities. Emphasis was placed on public utilities since the distribution of electricity has traditionally been the principle concern of public utilities.

The same two alternative procedures used to estimate hydro incentives were applied to the calculation of electricity incentives. Using the first procedure (Federal investment money outstanding), it was estimated that the costs of incentives were $\$ 64.5$ billion. With the second (interest rate incentive), the costs of incentives were estimated at $\$ 51.4$ billion. Most of these incentives to electricity generation and transmission constitute market activity and taxation actions by the Federal Government. 


\section{CONCLUSIONS}

In the years since 1918 the Federal Government has expended \$252 billion for incentives to stimulate energy production. A precedent therefore exists for the Federal Government to spend or forego large sums to increase energy production.

Considering the sums of the columns of Table 1, it can be seen that 0 il received the largest share of incentive funds. Possible reasons are 1) a large percentage of the population enters the oil market, at the gasoline pumps, each week; 2) o il has been commonly assumed to be difficult to find and in relatively limited supply; and 3 ) o il is perceived by the average citizen as necessary for a desirable lifestyle. The great value placed on oil by the public makes legislators sensitive to an assured supply.

The second largest share of Federal incentives went to the promotion of electricity generation and transmission. Reasons for this expenditure may have been the 'desirability of an inexpensive and readily available source of power for the public, The Rural Electrification Administration was created to provide the financing necessary to develop an electrical distribution system for all areas of the country.

Coal received the smallest percentage of incentives. The reasons may be: 1) coal has supplied energy over the longest period of time; 2) it is thought to be available in abundant quantities; and 3 ) coal is perceived as an inconvenient and dirty fuel. It therefore commands less political popularity.

Incentives for gas, nuclear, and hydro power have received intermediate amounts of funding. Production of gas is strongly related to the production of $\mathrm{oil}$ and the creation of incentives to increase oil production is correlated to that for gas. Incentives to the nuclear industry could result from 1) a strong puritan ethic which valued the making of something useful out of an investment conceived for destruction, and 2) a recognized need for new power sources. This was manifested as a dream of the future and articulated by the Joint Committee on Atomic Energy. The driving forces behind Federal expenditures for hydro power were largely social, as part of the taming of a raw land with flood control, irrigation, and recreational facilities. 
TABLE 1. An Estimate of tXe Cost Incentives Used to Stimulate Energy Production (in Billions of 1978 Dollars)

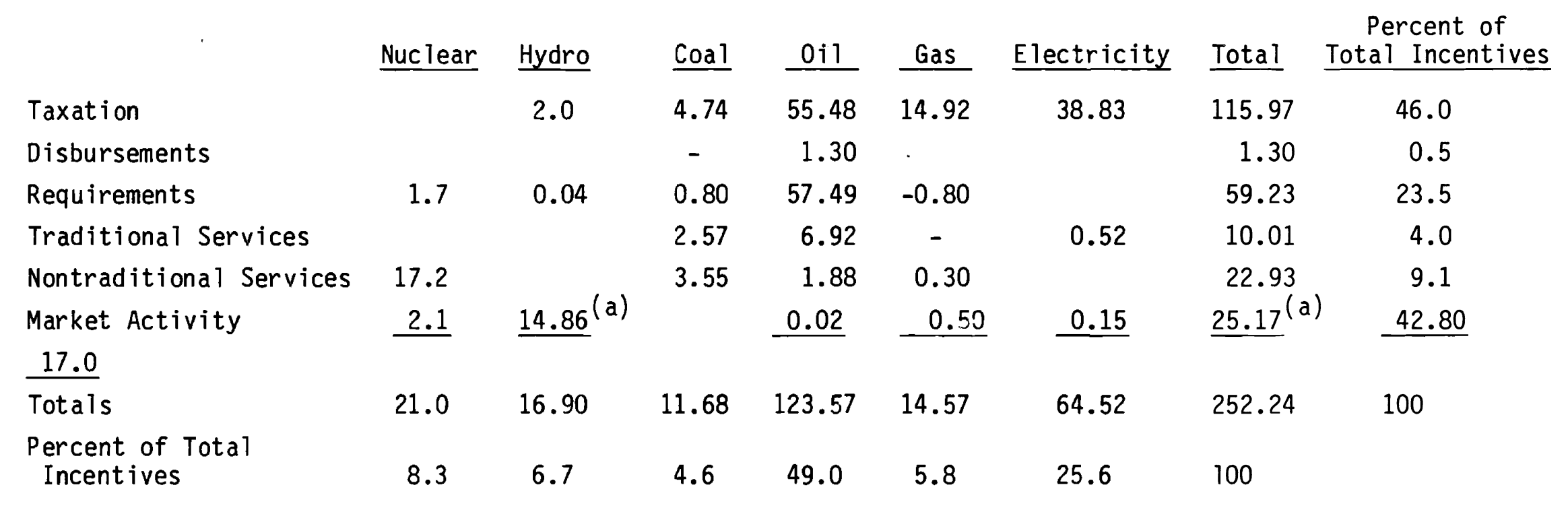

(a) This value based on incentive definition 1 (Federal money outstanding). 
Considering the sum of the rows of Table 1, it can be seen that $46 \%$ of the total cost of incentives could be categorized as the action of levying a tax or the exemption or reduction of an existing one. Taxation is relatively easy to administer, has an immediate financial impact on those affected, is flexible, and is expedient. Approximately $0.5 \%$ of the cost of incentives was in the form of disbursements for which the Federal Government received no direct or indirect good or service in return. Requirements, such as price controls, accounted for $23.5 \%$ of the incentives. The Federal Government allocated $9.1 \%$ of the money expended to create incentives for energy production through nontraditional services such as exploration, research, development, and demonstration. Though popular in promise, nontraditional services are not as flexible as taxation and requirements. One reason for this is the limited size of the research community, which cannot be readily expanded. Seventeen percent of the total expenditure for incentives to increase energy production involved government market activity such as TVA. Traditional government services accounted for $4 \%$ of the total. These, too, are inflexible.

Creation or prohibition of organizations, and collection of fees, have not been emphasized as incentives to increase energy production. Such incentives are often unpopular. When they are potentially feasible, as in the case of creating the TVA, they must be acted upon quickly.

The analysis indicates two apparent rationales for incentives: 1) promotion of a new technology during its early stages and 2) payment of the difference between the value of an activity to the private sector and its value to the public sector. The support of nuclear energy represents an example of the first justification. Examples of the second are rural electrification (REA), economic development (TVA), flood control (dams), and price controls (oil, gas, and coal). If solar policy were developed according to these rationales, twothirds of the action would focus on taxation and requirements. It would appear that these incentives should affect the technical elements of solar energy production for which consumers most often enter the marketplace.

During the course of the analysis, incentives were identified which did not have a quantifiable cost to the American taxpayer. Examples of these are 
the Price-Anderson liability indentification for nuclear power, the Connally Hot 0 il Act, the Interstate 0 il Compact Commission, and the Natural Gas Act of 1938. An analysis of the results of such incentives in which the Federal Government assumes responsibility and risk could lend considerable insight to the formulation of a strategy for solar development.

In conclusion, a precedent exists for utilizing Federal incentives to increase energy production. Design of national energy policy which considers the results of Federal investment in incentives to increase energy production could be an efficient basis upon which to integrate current and impending technology, existing energy stocks, and consumer requirements and preferences. The conclusion of micro-economic solar energy feasibility studies could be inconsequential without a comprehensive understanding of the costs and results of incentives to increase energy production. This is so because of the disparity in rationale between the Federal Government and the private sector. The Federal Government need not predicate national policy on short-term microeconomic analysis. As confirmed by this study, Federal justification is predicated on long-term goals met with the aid of new technology and supported by social values of the nation. If it is socially desirable and technologically feasible to increase solar energy's share in the national energy budget, the paramount policy question is one of selecting an incentive strategy and determining the government's level of investment in it. 



\section{PNL-2410 REV II \\ UC-59 \\ Executive Summary}

DISTRIBUTION

No. of

Copies

OFFSITE

25 Roger Bezdek

Chief

Division of Conservation and Solar Applications

Department of Energy

20 Massachusetts Avenue, N.W.

Washington, D 20545

Robert Spongberg

Solar Energy Research Institute 1536 Cole Blvd.

Golden, CO 80401

Wilson Clark

Assistant to the Governor for Issues and Planning

California State Governor's

Office

1400 10th st.

Sarcramento, CA 95814

Penny Plamann

Kansas Energy Office

503 Kansas Ave.

Topeka, KS 66603

George Hinman,

Director, Environmental

Research Center

Washington State University

Pullman, WA 99164

John Mitchner

Mail Stop 4723

Sandia Laboratories

P. 0. Box 5800

Albequerque, NM 87185

Jeff Hammarlund

7983 Maurer Rd.

Cross Plains, WI 53528
No. of

Copies

Bruce Macphee

Economist

Tennessee Valley Authority

1340 Commerce Union Bank Bldg.

Chattanooga, TN 37401

Raymond Anderson

Deputy Director

Office of Energy Management and Conservation

Washington State Energy Office

1000 South Cherry St.

Olympia, WA 98504

Michael Yoke11

Senior Economist

Solar Energy Research Institute

1536 Cole Blvd.

Golden, CO 80401

Gerald Savitsky, Editor

Energy User News

Fairchild Publications

7 E 12th St.

New York, NY 10003

Frederick Koomanoff, Chief

Environmental and Resource Studies Branch

Department of Energy

Washington, DC 20545

Thomas Sparrow

Purdue University

West Lafayette, IN 41906

Jon Veigel

Solar Energy Research Institute 1536 Cole Blvd.

Golden, CO 80401 
No. of

Copies

Charles R. Hauer

Consultant

Planning Research Corp.

7600 Old Springhouse Road

McLean, VA 22101

Jack Benveniste

Senior Staff Scientist

The Aerospace Corporation

P.O. Box 92957

Los Angeles, CA 90009

John Nassikas

Attorney

Cox, Langford \& Brown

21 Dupont Circle, NW.

Washington, DC 20035

Barry Hyman

Program in Social Management of Technology

University of Washington, FS-15

Seattle, WA 98195

Richard Watson

Research Asst. Professor

SMT Program

University of Washington

Seattle, WA 98195

A1 Williams

State Senator-District 32

4801 Fremont, N.

Seattle, WA 98103

James Easterling

Division of Conservation and Solar Applications

Department of Energy

20 Massachusetts Avenue, N.W.

Washington, DC 20545

Stephan Lanes

House Science Committee

B-374 Rayburn Building

Washington, DC 20515
No. of

Copies

Douglas R. Boleyn, P.E.

Energy Management Consultant

17610 Springhil] Place

Gladstone, OR 97027

Rocky Wi 1 son

Co-Edit or

The Times Journal

Box 746

Condon, OR 97823

Chandler Thompson

Technical Writer

New Mexico Solar Energy Institute

Box $3 \mathrm{SOL}$

Las Cruces, NM 88003

Leon Lindberg

Professor

Department of Political Science

University of Wisconsin-Madison

North Hall

1050 Bascom Mall

Madison, W I 53706

Ronald Doctor, Commissioner

California Energy Resources

Development Commission

1111 Howe Avenue

Sacramento, CA 95825

Wm H. Babcock

Director of Policy and Economic

Analysis for PRC Energy Analysis Co. 7600 Old Springhouse Road

McLean, VA 22101

A A. Churm

DOE Patent Division

9800 S. Cass Avenue

Argonne, IL 60439

Andrew Krantz

Division of Solar Energy

Department of Energy

Washington, DC 20545 
No. of

$\underline{\text { Copies }}$

Paul Maycock

Division of Solar Energy

Department of Energy

Washington, DC 20545

George Kaplan

Solar-Central Receiver Branch

Department of Energy

Washington, DC 20545

Mart in Gutsten

Solar-Thermal Systems R\&D

Department of Energy

Washington, DC 20545

G. W. Brown

Solar Thermal

Department of Energy

Washington, DC 20545

Bob Stewart

Department of Energy

Richland Office

Richland, 99352

314 DOE Technical Information Center

William D. Beverly

17778-41st Avenue, South

Seattle, 98124

John S. Reynolds

Department of Agriculture

University of Oregon

Eugene, OR 97403

David E. McDaniels

Physics Department

University of Oregon

Eugene, OR 97403

Loren Johnson

$2270 \mathrm{~N}$ W. Irving Street

Portland, OR 97210

George W. Wyes

7617 S. W. 24th Avenue

Portland, OR 97219
No. of

$\underline{\text { Copies }}$

George A. Tsongas

Engineering \& Appl. Sciences

Portland State University

Portland, or 97207

Mary Lawrence

4015 S. W. Canyon Road

Portland, OR 97221

Wendell E. Newson

Department of Atmospheric Sciences

Oregon State University

Corvallis, OR 97330

Elliot Katz

Aerospace Corporation

P.O. Box 92957

Los Angeles, CA 90009

Herbert Costner

Division of Social Sciences

National Science Foundation

1800 G Street, N.W.

Washington, DC 20006

Esther Cassidy

Office of Congressional Affairs

12 th and Pennsylvania, NW

Washington, DC 20461

Joey Skaff

Department of Energy Library

Room 1223

20 Massachusetts Avenue, IW

Washington, DC 20545

Howard Bucknell, II I

P.O. Box 1508

East Hampton, NY 11937

Orval Bruton

North Pacific Division

US Amy Corps of Engineers

P.O. Box 2870

Portland, OR 97208 
No. of

Copies

Richard L. Mittelstadt

North Pacific Division

US Army Corps of Engineers

P.O. Box 2870

Portland, OR 97208

Leon Joroulman

US Department of Interior

Bonneville Power Administration

$919 \mathrm{NE} 19$ th Avenue

Portland, OR 97208

Jerry Dinan

US Department of Interior

Bonneville Power Administration

919 NE 19th Avenue

Portland, OR 97208

0. P. Pitts

Tennessee Valley Authority

815 Power Building

Chattanooga, $\mathbb{N} 37401$

John Lopez

Tennessee Valley Authority

815 Power Building

Chattanooga, $\mathbb{T N} 37401$

Kathleen Berry

US Department of Interior

Alaska Power Administration

P.O. Box 50

Juneau, AK 99802

\section{Lenore Melin}

US Department of Interior

Alaska Power Administration

P.O. Box 50

Juneau, AL 99802

Gordon Hallum

US Department of Interior

Alaska Power Administration

P.O. Box 50

Juneau, AK 99802
No. of

$\underline{\text { Copies }}$

Edward E. Riggin

US Department of Interior

Southwestern Power Administration

Page Belcher Federal Building

Tulsa, $\mathbb{Q} 74101$

Lee C. Sheppeard

Tennessee Val Tey Authority

Knoxville, TN 37902

Jesse C. Mills

Tennessee Valley Authority

Knoxville, $\mathbb{T N} 37902$

Wade Rose

Governor's Office

1400 10th St.

Room 108

Sacramento, CA 95814

Commissioner of Reclamation

Room 7654

Department of the Interior

Washington, DC 20240

Mary George Bond

US Department of Interior

Southeastern Power Administration

Elberton, GA 30635

H Wright

US Department of Interior

Southeastern Power Administration

Elberton, GA 30635

John E. Bigger

Solar Energy Program

EPRI

3412 Hillview Avenue

Palo Alto, CA 94303

George P. Branch

Program Manager

Hexce 1

11711 Dublin Boulevard

Dublin, CA 94566 
No. of

$\underline{\text { Copies }}$

Peter H. Rose

Matematical Sciences NW Inc.

P.O. Box 1887

Bellvue, WA 98009

John M. Musser

Weyerhauser Company

First National Bank Building

St. Paul, MN 55101

Myron B. Katz

Northwest Energy Policy Project

Pacific Northwest Regional

Commission

1097 Lloyd Building

700 NE Multnomah Street

Portland, OR 97232

McLaren Stinchfield

The Times-Journal

P.O. Box 746

Condon, or 97823

Carol S. Harlow

Office of Environmental Affairs

Seattle City

1015 Third Avenue

Seattle, WA 98104

John Hogan

City Energy Office

914 Arctic Building

Seattle, WA 98104

Alan Matthews

R. W. Beck and Associates

16009 NE 57th Street

Redmond, WA 98055

Kenneth D. Smith

Ecotope Group

2332 East Madison

Seattle, WA 98112

George Textor

Seattle Trust and Savings Bank

Fourth \& Union Branch

Seattle, 98101
No. of

Copies

Richard H. Watson

Social management of Technology

University of Washington FS-15

Seattle, WA 98195

William D. Schulze

Department of Economics

New Mexico University

Albuquerque, NM

Douglas R. Bolste

17610 Springhill Place

Gladstone, OR 97027

Gary D. Somon

California Energy Commission

1111 Howe Avenue

Sacramento, CA 95825

Craig Chase

Department of Energy

1992 Federal Bldg.

915 2nd Avenue

Seattle, WA 98174

Ken Bostock

Washington Energy Office

1000 South Cherry St.

Olympia, 98504

Ron Quist

Senior Research Analyst

Seconf Floor

House Office Building

Olympia, WA 98504

Vincent DiCara

Office of Energy Resources

55 Capitol St.

August, ME 04330

Joseph Honick

Group Mangement Associates

Suite 715

Encina, CA 91436 
No. of

Copies

Robert Scot

CBNS

Campus Box 1126

Washington University

St. Louis, MO 63130

Michael W. Grainey, Esq.

Special Assistant to the Director

Department of Energy

State of Oregon

Salem, OR 97310

A. Verrips

American Public Gas Assn.

Suite 115

2600 Virginia Avenue, NW

Washington, DC 20037

Bruce Chapman

Secretary of State

Legislative Building

0lympia, WA 98504

R. Schedigar

NM Solar Energy Institute

Las Cruces, NM 88003

Edward W. Ware II I

American Gas Association

1515 Wilson Blvd.

Arlington, VA 22209

Michael Totten

National Taxpayers Union

325 Pennsylvania Avenue, $\mathbb{E}$

Washington, DC 20003

Thomas Scan 1 on

Project Office

Rural Electrification Administration, Department of Agriculture

14th Street and Independence Ave., Washington, DC 20250

Bill Weigle

1620 North Park Avenue

Tucson, AZ 85719
No. of

Copies

Mike McCabe

Environmental Study Conference

3334 House Annex 2

us Congress

Washington, DC 20515

Susannah Lawrence

Non-Congressional Coordinator of Solar

317 Penn. Ave. $\mathbb{E}$

Washington, DC 20003

Daniel Drayfus

Committee on Energy and National Resources

US Senate

Dirson Office Building

Washington, DC 20510

Dick D'Amato

US Congress

429 Cannon Office Building

Washington, DC 20515

Terry Johnson

Senator Hart's Office

254 Russell Office Building

Washington, DC 20510

Tom Smith

University of Wisconsin Extension

Department of Engineering

$432 \mathrm{~N}$. Lake St.

Madison, WN 53706

Meg Schachter

National Center for Economic Alternatives

2000 P Street, NW

Suite 515

SV

Wash ington, D 20510

Pau1 Rothberg

RS-SPR

Library of Congress

$1 \mathrm{st}$ and Independence Ave. $\mathbb{E}$

Washington, DC 20540 
David Gushee

Congressional Research Service Library of Congress

Washington, DC 20540

Robert L. Vines

Bituminous Coal Operators Assn., Inc.

World Center Building

Washington, DC 20036

Thomas E. Biery

Director Policy Analysis

Independent Petroleum Assn.

of American

1101 16th Street, NW

Washington, DC 20036

Alan Starr

Economics Regulatory Administration

Office of Utilities Systems

US Department of Energy

20 Massachusetts Ave., NW

Washington, DC 20545

Allen Hirshberg

Booze-A1len-Hami1ton Mgmt. Consultants

1025 Connecticut Ave., NW

Bethesda, MD 20014

Dr. David Bushnell

9620 Hawick Lane

Kensington, ME 20795

Kay McSweeney

PATRIOT-LEDGER

13 Temple St.

Quincy, MA 02169

Jet Propu $7 s i o n$ Laboratory/CALTECH

ATTN: Library Tech. Operations $\# 1680$

4800 Oak Grove Drive

Pasadena, CA 91103

Attn: Lois M. Baird
Randi Lornell

Solar Energy Research Institute

1536 Cole Blvd.

Golden, CO 80401

Jack Cadogan

Department of Energy (ETS)

600 E. St., NW

Washington, DC 20545

John Davidson, CEQ

722 Jackson Place

Washington, DC 20006

Tom Friery

Office of Sacramento

City Treasurer

800-10th St.

Sacramento, CA 95814

Robert T. Jaske

Nuclear Regulatory Commission

Office of State Programs

Washington, DC 20555

Roger W. Bryenton

956 East 16th Avenue

Vancouver, $B C$

V5T 2V9, CANADA

Allan Brosz

Science and Public Policy Program University of Oklahoma

Norman, Ox 73019

W. R. McCuney

Program Director

Florida Solar Energy Center

300 State Road 401

Cape Canaveral, FL 32920

John Fattorini

House Republican Caucus

Legislative Building

Olympia, WA 98504 
No. of

Copies

Charles McClain

House Republican Caucus

Legislative Building

Olympia, WA 98504

Iraida B. Rickling

Librarian

Florida Solar Energy Center

300 State Road 401

Cape Canaveral, FL 32920

Dr. Haskell P. Wald

Chief Economist

Federal Power Commission

Washington, DC 20426

Thomas D. Duchesneau

University of Maine at Orono

Orono, ME 04473

Reed Moyer

Michigan State University

East Lansing, M I 48823

John L. Siegfried

Assistant Professor Economics

Vanderbilt University

Nashville, $\mathbb{N} 37240$

Edwin Mansfield

Wharton School

University of Pennsylvania

Philadelphia, PA 19174

Thomas F. Hogarty

Dept. of Econ.

Virginia Polytechnic Institute and State U

Blacksburg, VA 24060

Dr. Thomas Gale Moore

Dept. of Econ.

Michigan State U

East Lansing, M I 48823

John H. Lichtblau

Pet. Industry Research Foundation

122 E. 42 St.

New York, NY 10017
No. of

Copies

George Patton

American Petroleum Institute

21st and L St.

Washington, DC 20006

Connie Holmes

National Coal Assn.

1130 17th, NW

Washington, D 20036

Lester M. Salamon

Asst. Prof. of Political Science

Duke University

Durham, NC 27706

Professor Gerard M. Brannonall

Georgetown University

140037 th, NW

Washington, DC 20057

Robert Kalisch

American Gas Assn.

1515 Wilson Blvd.

Arlington, VA 22209

Sheldon Butt

Solar Energy Industry Assn.

Suite 800

1001 Connecticut Ave., NW

Washington, D 20036

Robert Perry

Director, Systems Acquisition Management

1700 Main Street

Santa Monica, CA 90406

Dr. Meir Carraso, Mgr.

Energy Systems Integration

California Energy Resources

Conservation and Development Commission

111 Howe Avenue

Sacramento, CA 95825 
No. of

$\underline{\text { Copies }}$

Kenny Cousins

c/o Senator Paul Tsongas

Senate Office Bldg.

Washington, DC 20515

Chris Byal

Public Interest Economics

1095 Market St.

Suite 604

San Francisco, CA 94103

Bruce Hannon

Associate Professor

Director - Energy Research Group

University of Illinois at Urbana-Champaign

Center for Advanced Computation

Urbana, IL 61801

Dr. Paul Rappaport, Director

Solar Energy Research Institute

1536 Cole Blvd.

Golden, CO 80401

Dr. Barbara C. Farhar

Solar Energy Research Institute

1536 Cole Blvd.

Golden, CO 80401

Silvio J. Flaim, Ph.D.

Solar Energy Research Institute

1536 Cole Blvd.

Golden, CO 80401

Dennis R. Costel10

Solar Energy Research Institute

1536 Cole Blvd.

Golden, CO 80401

Duane Chapman

Energy \& Resource Program

Room 100, Building T-4

Berkeley, Ca 94720
No. of

$\underline{\text { Copies }}$

James Hardcastle

Energy Research Digest

Dulles Intern'1 Airport

P.O. Box 17162

Washington, DC 20041

The Wall Street Journal

1701 Page M ill Road

Palo Alto, CA 94304

Carol Anderson

National Resources Defense Counci 1

917 15th St., NW

Washington, DC 20005

Jerry Duane

Building and Community Systems Division

20 Massachusetts NW,

Room 2248

Washington, DC 20545

Max Goldman

Texaco Inc.

Suite 500

1050 17th St. NW

Washington, DC 20036

Jane Gravelle

Economic Division

Congressional Research Service

Library of Congress

Main Building

1st Floor - West Side, Room 103

Washington, DC 20540

H. Richard Chew,

Attorney at Law

Suite 312 Radio Bldg.

2030 N. 16th Street

Arlington, VA 22201

Ronald W. Szwajkowski

Mayer, Brown and Platt

231 South La Salle Street

Chicago, IL 60604 
No. of Copies

H. Dana Moran

Solar Energy Research Institute 1536 Cole Blvd.

Golden, CO 80401

Harvey A Harris

Attorney at Law

Stolar, Heitzmann \& Eder

515 Olive Street

Room 1700

St. Louis, MO 63101

Daniel L. Skoler

Program Development Counsel

American Bar Assoc.

1800 M Street NW

Washington, DC 20036

Harold P. Green

Professor. of Law

The National Law Center

The George Washington University

720 20th Street MW

Washington, DC 20006

Katherine McG. Sullivan

Assistant Director

Public Service Activities Div.

American Bar Assoc.

1800 M Street M

Washington, X 20036

Jan G. Laitos

Ass' $t$ Professor of Law

University of Denver College of Law

200 W. 14th Ave.

Denver, CO 80204

Bob Lindsey

706 Federal Bldg.

Department of Energy

Richland Office

Richland, WA 99352
No. of

Copies

Earl Finbar Murphy

Ohio State University College of Law

1659 N. High St.

Columbus, 어 43210

William A Thomas

American Bar Foundation

1155 E. 60th Street

Chicago, IL 60637

George R. Perrine

Legal Consultant

Tenneco Inc.

Suite 4300-1100 Milan Bldg.

P.O. Box 2511

Houston, TX 77001

Prof. Gary W idman

Hastings College of Law

198 McAllister St.

San Francisco, CA 94102

Patrick Donnelly

Office of Public Affairs

Department of Energy

12th and Pennsylvania Avenue

Washington, DC 20461

Michael Silverstein, President

Energy Marketing Associates

c/o Energy User News

7 E. 12th Street

New York, NY 10003

William Fenzel

U.S. General Accounting Office

Room A2-2200

Century 21 Building

cv/o Department of Energy

Washington, DC 20545

James Eberhardt

Division of Conservation and

Solar Applications

Department of Energy

20 Massachusetts Avenue N. W.

Washington, DC 20545 
No. of

$\underline{\text { Copies }}$

Richard N. Bergstrom

Partner -- Sargent \& Lundy

55 East Monroe

Chicago, IL 60603

E. Sturt Kirkpatrick

P.O. Box 236

Berkeley Springs, WV 25411

J. George Thon

465 Barbara Way

Hillsborough, CA 94010

Harry E. Bovay

Bovay Engineers, Inc.

5009 Caroline

Houston, TX 77004

Richard S. McGinn is

Northern States Power co.

414 Nicollet Mall

Minneapolis, MN 55401

Franklin D. Meyers

Inter-County Highway Commission of $\mathbb{E}$ Michigan

24719 Van Dyke

Center Line, MI 48105

Don P. Reynolds

ASCE, 345 East 47th Street

New York, NY 10017

Louis L. Meier, Jr.

ASCE, 1625 Eye St., M

Washington, DC 20006

\section{ONSITE}

DOE Richland Operations Office

Programs Division

H. E. Ranson
No. of

$\underline{\text { Copies }}$

133 Pacific Northwest Laboratory

$\begin{aligned} 10 & \text { D. Brenchley } \\ 10 & \text { R. Cole (HARC) } \\ & \text { W. Coleman } \\ 50 & \text { B. Cone } \\ & \text { D. Deonigi } \\ 5 & \text { K. Drumheller } \\ 5 & \text { J. Emery } \\ 10 & \text { A. Fassbender } \\ & \text { J. Fox } \\ & \text { J. Goodnight (HARC) } \\ & \text { R. Gurwall } \\ 10 & \text { H. Harty } \\ & \text { F. Hungate } \\ & \text { E. Kleckner } \\ & \text { D. Lenerz (Columbus) } \\ & \text { J. Litchfield } \\ & \text { J. Maxwell (HARC) } \\ 5 & \text { R. Mazzucchi } \\ & \text { J. Ramsdel1 } \\ 10 & \text { W. Sheppard (Columbus) } \\ & \text { P. Sommers (HARC), } \\ & \text { G. Stacy (Columbus) } \\ & \text { P. Walkup } \\ & \text { R. Watts } \\ & \text { 0. Williams } \\ 3 & \text { Economics Library } \\ 5 & \text { Technical Information } \\ 2 & \text { Publishing Coordination }\end{aligned}$


